\title{
TANGGUNG JAWAB DOKTER DALAM PENERAPAN PENGEMBANGAN KEILMUAN, PENELITIAN DAN PENGEMBANGAN KESEHATAN DIHUBUNGKAN DENGAN UNDANG-UNDANG NOMOR 36 TAHUN 2009 TENTANG KESEHATAN DAN UNDANG-UNDANG NOMOR 29 TAHUN 2004 TENTANG PRAKTIK KEDOKTERAN
}

\author{
Evy Silviani Agustina \\ Alumni Magister Ilmu Hukum Pascasarjana Unisba \\ Pengajar Pada LKP Profesional Medis Medicuss Group Bandung \\ e-mail : evy.silviania@gmail.com
}

\begin{abstract}
Abstrak - Perkembangan teknologi kesehatan sering menimbulkan kontroversi masalah etik, hukum dan manfaatnya bagi masyarakat, seperti kasus cuci otak dan terapi kanker dengan obat racikan atau alat temuan baru. Masalah yang diteliti adalah bagaimana tanggung jawab hukum dokter dalam penerapan pengembangan keilmuan, penelitian, dan pengembangan kesehatan dihubungkan dengan Undang-Undang No. 36 Tahun 2009 tentang Kesehatan dan Undang-Undang No. 29 Tahun 2004 tentang Praktik Kedokteran. Metoda penelitian yang digunakan adalah deskriptif analitik dengan pendekatan normatif yuridis. Data dianalisis secara analitis kualitatif sehingga menghasilkan data deskriptif analitis.. Hasil penelitian didapatkan adanya pelanggaran terhadap hubungan perikatan antara dokter dengan pasien, pelanggaran terhadap standar profesi medis, kode etik kedokteran Indonesia, etika penelitian kesehatan, disiplin kedokteran dan peraturan perundang-undangan. Situasi ini menjadi polemik saat MKEK menjatuhkan sanksi karena pelanggaran etik berat.
\end{abstract}

Kata kunci : Tanggung jawab dokter, pengembangan keilmuan, penelitian, pengembangan kesehatan.

Abstract - The development of health technology often cause controversy between ethical problem, law and the benefits for the community, such as btain wash and cancer teraphy with medicinal concoction or new tool. Problem which were research were how doctor responsibility in the eyes of the law in the application of scientific development, research, and health development related to health law No. 36 of 2009 and medical practice law No. 29 of 2004. . The Method used in this study is analytical descriptive with juridical normative approach. The data was then analyzed by qualitative analysis to produce analytical descriptive data. The result of this study show there was infraction that enforced by the doctors for instance patient and doctor relationship, infringement to the medical profession standards, medical ethic code, health research ethic, medical discipline, and law. This situation is becoming a polemic when Indonesian Medical Ethical Board (MKEK) gave ethical sanctions for doing heavy ethical violations.

Keywords : Doctors liability, science development, research, health development.

\section{A. PENDAHULUAN}

\section{Latar Belakang}

Ilmu dan praktik kedokteran, seperti halnya hukum, nilai dan norma sosial merupakan hal yang sangat dinamis, bukan merupakan hal yang statis. Pergeseran dinamika nilai dan disiplin dalam praktik kedokteran dipengaruhi oleh berbagai faktor yang salah satunya adalah penelitian serta perkembangan ilmu dan teknologi kedokteran yang pesat. Pelaksanaan 
pelayanan kesehatan dengan standar profesi tertinggi membuat seorang dokter harus dibekali dengan tingkat kemampuan dan ilmu pengetahuan yang mumpuni dan selalu senantiasa harus melakukan pengembangan dirinya terhadap ilmu pengetahuan dan teknologi yang terus berkembang

Teknologi dan produk teknologi kesehatan harus terus diteliti, dikembangkan dan dimanfaatkan untuk kesehatan masyarakat. Dokter harus bertanggung jawab dalam melakukan dan mengikuti perkembangan ilmu pengetahuan dan teknologi sesuai dengan yang tercantum pada Kode Etik Kedokteran Indonesia, UU No. 29 tahun 2004 tentang Praktik Kedokteran, UU No. 36 Tahun 2009 tentang Kesehatan dan UU No. 36 tahun 2014 tentang Tenaga Kesehatan.

Perkembangan teknologi dalam dunia kesehatan sering menimbulkan kontroversi antara masalah etik, hukum dan manfaatnya bagi masyarakat, misalnya kasus Metode Digital Substraction Angiography (DSA) atau yang dikenal dengan "Brain Wash" atau cuci otak yang diterapkan oleh dokter Terawan. Kasus serupa yang mirip adalah kasus dokter Gunawan Simon yang melakukan "cara baru" penyembuhan penyakit kanker dengan melakukan racikan obat sendiri untuk pasiennya, Kasus lain adalah mengenai penemuan alat Electro Capacitance Volume Tomography (ECVT) untuk mendiagnosis kanker dan Electro Capacitance Cancer Theraphy (ECCT) sebagai terapi kanker, yang izinnya dihentikan atas rekomendasi dari Kementrian Kesehatan dengan alasan kegiatan yang dilakukan tidak sesuai dengan tahapan proses penelitian yang sudah ditetapkan badan penelitian dan pengembangan Kementrian Kesehatan perihal jaminan keamanan dan kemanfaatan penerapan pada manusia. Permasalahan-permasalahan ini perlu disikapi dengan bijaksana agar mendapatkan solusi yang terbaik, terlebih bila inovasi tersebut satu-satunya ciptaan anak bangsa Indonesia yang membanggakan dan memberikan manfaat bagi masyarakat luas.

\section{Rumusan Masalah}

1. Bagaimanakah tanggung jawab hukum dokter dalam penerapan pengembangan keilmuan, penelitian dan pengembangan kesehatan dihubungkan dengan UndangUndang No. 36 Tahun 2009 tentang Kesehatan? 
2. Bagaimanakah tanggung jawab hukum dokter dalam penerapan pengembangan keilmuan, penelitian dan pengembangan kesehatan dihubungkan dengan UndangUndang No. 29 Tahun 2004 tentang Praktik Kedokteran?

\section{Metode Penelitian}

Penelitian ini dilakukan dengan menggunakan metode penelitian deskriptif analitik melalui pendekatan normatif yuridis, menggunakan data sekunder berupa bahan hukum yang ada kaitannya dengan masalah yang diteliti. Data kemudian dianalisis secara analitis kualitatif sehingga menghasilkan data deskriptif analitis.

\section{B. PEMBAHASAN}

1. Tanggung jawab hukum dokter dalam penerapan pengembangan keilmuan, penelitian dan pengembangan kesehatan dihubungkan dengan UndangUndang No. 36 Tahun 2009 tentang Kesehatan.

Undang-undang No. 36 Tahun 2009 tentang kesehatan menyebutkan bahwa setiap kegiatan dalam upaya memelihara dan meningkatkan derajat kesehatan masyarakat yang setinggi-tingginya dilaksanakan berdasarkan prinsip non diskriminatif, partisipatif, dan berkelanjutan dalam rangka pembentukan sumber daya manusia Indonesia, serta peningkatan ketahanan dan daya saing bangsa bagi pembangunan nasional. Hal ini dapat tercapai apabila didukung oleh adanya dasar ilmu pengetahuan yang kuat dan metode-metode pengobatan terbaik agar dapat mendukung terlaksananya peningkatan derajat kesehatan tersebut.

Teknologi kesehatan sendiri seperti yang disebutkan pada penjelasan pasal 42 Undang-Undang No. 36 Tahun 2009 tentang kesehatan, merupakan suatu produk yang dihasilkan dari penerapan dan pemanfaatan disiplin ilmu pengetahuan dibidang kesehatan yang menghasilkan nilai bagi pemenuhan kebutuhan, kelangsungan dan peningkatan mutu kehidupan manusia. Hal ini merupakan bagian dari upaya kesehatan yang bersifat promosi kesehatan, pencegahan penyakit (preventif), pelayanan kesehatan kuratif berupa kegiatan pengobatan yang ditujukan untuk penyembuhan, pengurangan penderitaan akibat penyakit, pengendalian penyakit, atau pengendalian kecacatan, serta pelayanan rehabilitatif. 
Kasus yang saat ini ramai dibicarakan adalah perihal kasus dokter Terawan yang menerapkan metode "Brain Wash" atau cuci otak untuk pasiennya, atau kasus dokter Gunawan Simon yang melakukan "cara baru" penyembuhan penyakit kanker dengan obat racikan sendiri untuk menangani pasien-pasiennya, dan kasus serupa lainnya yaitu dengan ditemukannya alat Electro Capacitance Volume Tomography (ECVT) untuk mendiagnosis kanker dan Electro Capacitance Cancer Theraphy (ECCT) sebagai terapi kanker yang ditemukan oleh seorang ilmuwan teknik yaitu DR. Warsito.

Bercermin dari kasus dokter Terawan ada beberapa hal yang dirasakan tidak sesuai dengan aturan penelitian yang telah ada. Penelitiannya seolah-olah memberikan janji berupa tercapainya pemulihan bagi penderita stroke padahal pada kenyataannya hanya pemulihan aliran darah. Seorang dokter yang menerapkan suatu penemuannya dan bahkan seolah-olah menjanjikan suatu kesembuhan bila menjalankan metode tersebut, dianggap sebagai tindakan yang tidak sesuai dengan pola hubungan dokter pasien yang merupakan suatu hukum perikatan yang diatur dalam KUHPerdata
Pasal 1320. Pada kasus diatas terdapat ketidakjujuran, ketidakjelasan dalam penyampaian informasi dimana penerapan metode terapi tanpa melalui uji klinis, sama halnya dengan melakukan penipuan atau kesilapan terhadap pasien, sehingga melanggar syarat sah subjektif dari suatu perjanjian yaitu adanya kesepakatan para pihak dan melanggar syarat sah objektif, yaitu tidak berbuat baik, merugikan dan bertentangan dengan hukum sehingga tidak memenuhi syarat perihal tertentu dan kausa yang halal. Pada umumnya hubungan dokter dengan pasien terbangun berdasarkan perjanjian upaya (inspanningverbintenis), dalam hal ini seorang dokter berjanji berdaya upaya secara semaksimal mungkin untuk mewujudkan apa yang terbaik yang diperjanjikan bagi pasiennya, bukan berdasarkan suatu hasil yang nyata (resultaatverbintenis). Menjanjikan suatu kesembuhan bagi pasien dengan metode tertentu akan melanggar pola hubungan dokter pasien dari sisi hukum perikatan tersebut.

Kasus Terawan menjadi kontroversi karena sebelum dilakukan uji klinis dari hasil penelitiannya, dokter tersebut telah mengaplikasikan metode cuci otak bagi pasien-pasiennya. Metode 
yang diterapkan Terawan masih harus melalui pengujian lebih lanjut dikarenakan berhubungan dengan bahaya atau efek samping yang kemungkinan muncul, apalagi bila uji ini diterapkan pada kelompok dengan skala besar. Dalam hal ini dokter tersebut telah melanggar ketentuan pasal 44 UndangUndang No. 36 tahun 2009 tentang kesehatan yang menyebutkan bahwa dalam melakukan pengembangan teknologi kesehatan dilakukan melalui uji coba teknologi terhadap manusia atau hewan, dan uji coba yang dilakukan tidak boleh merugikan manusia yang dijadikan uji coba. Terawan tidak memperhatikan ketentuan ini, dia bahkan telah menerapkan penemuannya pada pasien-pasiennya tanpa uji coba klinis dengan resiko keamanan yang belum jelas. Hal ini juga melanggar ketentuan pasal 15 Peraturan Pemerintah Nomor 39 Tahun 1995 Tentang Penelitian dan Pengembangan Kesehatan, dimana disebutkan bahwa penerapan hasil penelitian dan pengembangan kesehatan pada tubuh manusia hanya dapat dilakukan setelah sebelumnya diterapkan pada hewan percobaan, sehingga dapat dipertanggungjawabkan dari sisi kesehatan dan keselamatan jiwa manusia.
Belum terujinya keamanan dan resiko dari hasil metode temuan Terawan, menjadikan kemungkinan penerapan metode ini dapat membawa resiko buruk bagi orang yang melakukannya, hal ini melanggar pasal 45 ayat (1) UndangUndang No. 36 tahun 2009 tentang kesehatan yang menjelaskan bahwa setiap orang dilarang mengembangkan teknologi atau produk teknologi yang dapat memberikan resiko buruk terhadap kesehatan masyarakat.

Peraturan Pemerintah RI no. 48 Tahun 2009 Tentang Perizinan Pelaksanaan Kegiatan Penelitian, Pengembangan, dan Penerapan Ilmu Pengetahuan dan Teknologi Yang Beresiko Tinggi dan Berbahaya Penelitian Terawan termasuk ke dalam penelitian yang beresiko tinggi dan berbahaya karena bidang kegiatannya termasuk dalam bidang pengembangan teknologi kesehatan, hal ini disebutkan pada penjelasan Pasal 5 ayat (2) huruf a yang menyebutkan bahwa salah satu yang termasuk ke dalam daftar bidang penelitian beresiko tinggi dan berbahaya adalah penelitian di bidang pengembangan teknologi kesehatan dan obat. Penelitian Terawan dikatakan beresiko tinggi karena penerapan metode 
ini sifatnya langsung, mempunyai potensi membahayakan, mencemarkan dan merusak hidup manusia. Dikatakan berbahaya karena menggunakan zat yang berpotensi menimbulkan efek samping serius sampai kematian. Pada pasal 3 peraturan diatas disebutkan bahwa kegiatan litbangrap Iptek yang beresiko tinggi dan berbahaya hanya dapat dilakukan atas dasar izin tertulis dari pemerintah, dimana dalam hal ini harus mendapatkan izin dari Komite Etik Penelitian dan Pengembangan Kesehatan Nasional (KEPPKN).

Peraturan Menteri Kesehatan RI No. 7 Tahun 2016 Tentang Komisi Etik Penelitian dan Pengembangan Kesehatan Nasional menyatakan bahwa penelitian dan pengembangan kesehatan yang mengikutsertakan manusia sebagai subjek dan memanfaatkan hewan coba sebagai subjek harus sesuai dengan pedoman kaidah etika penelitian (Keputusan Menteri Kesehatan RI Nomor 1031/Menkes/SK/VII/2005). Butir pedoman 2 kaidah etika penelitian kesehatan yang menyatakan bahwa semua protokol penelitian yang mengikut sertakan manusa harus diajukan untuk dinilai kebaikan ilmiahnya dan kepantasan etiknya oleh KEPPKN, untuk kemudian akan diberikan persetujuan etik (ethical clearance) oleh KEPPKN. Penelitian Terawan tidak melalui proses sesuai dengan yang tertera pada pedoman diatas, dia bahkan langsung menerapkan penelitiannya pada pasien-pasiennya tanpa melalui prosedur ethical clearance terlebih dahulu.

Penelitian yang dilakukan, seharusnya melalui 4 tahapan uji klinis yang sesuai, dan semua uji coba yang menggunakan manusia sebagai subjek wajib didasarkan pada tiga prinsip etik umum, yaitu menghormati harkat martabat manusia (respect for persons) yang bertujuan menghormati otonomi dan melindungi manusia yang otonominya terganggu/kurang, berbuat baik (beneficience), tidak merugikan (nonmaleficience) dan keadilan (justice).

Proses tahapan uji klinis ini tidak dilakukan oleh Terawan, sehingga timbul keraguan apakah manfaat yang didapatkan melalui penerapan penelitiannya bermakna atau tidak, bila dibandingkan dengan resiko yang kemungkinan akan timbul. Dengan menerapkan penelitian yang belum diketahuai manfaat dan resikonya secara benar, Terawan juga jelas melakukan 
pelanggaran terhadap tiga prinsip umum etik diatas.

\section{Tanggung jawab hukum dokter} dalam penerapam pengembangan keilmuan, penelitian dan pengembangan kesehatan dihubungkan dengan UndangUndang No. 29 Tahun 2004 tentang Praktik Kedokteran

Penjelasan pasal 2 Undang-Undang Praktik kedokteran menyebutkan pentingnya peran nilai ilmiah, bahwa praktik kedokteran harus didasarkan pada ilmu pengetahuan dan teknologi yang diperoleh baik dalam pendidikan termasuk pendidikan berkelanjutan maupun pengalaman serta etika profesi. serta harus memberikan manfaat bagi kemanusiaan, mempertahankan dan meningkatkan derajat kesehatan masyarakat.

Dunia kedokteran mengenal istilah ini sebagai Evidence Based Medicine $(E B M)^{1}$ dan setiap tindakan yang dilakukan dokter harus mengacu pada EBM ini. Pada kasus Terawan didapatkan kelemahan nilai ilmiah yang dijadikan dasar dari metodenya, yaitu :

\footnotetext{
1 Amit Kaura, Crash Course Evidence-Based Medicine : Reading and Writing Medical Papers, Mosby Elsevier, London, 2013, Hlm 1
}

1. Penggunaan heparin untuk pasien stroke karena sumbatan. Pada panduan pengobatan stroke yang dikeluarkan oleh American Heart Association (AHA) dan American Stroke Association (ASA ${ }^{2}$ ) merekomendasikan ateplase sebagai terapi kasus stroke karena sumbatan, bukan penggunaan heparin, sedangkan Terawan menggunakan heparin melalui metode brain washnya untuk mengobati kasus stroke karena sumbatan ini.

2. Terawan menggunakan dasar ilmiah yang keliru sebagai landasan teorinya. Ia menggunakan referensi penelitian dari Guggenmos (2013) dan Schwerin (2013), ${ }^{3}$ bahwa menurut Guggenmos perbaikan stroke dapat dilakukan dengan implantasi microelectrodes di otak, sedangkan Schwerin hanya membahas mengenai fungsi motorik badan yang diatur oleh korteks

\footnotetext{
${ }^{2}$ William J. Power et al, Guideline For The Early Management of Patients With Acute Ischemic Stroke, American Heart Association, Inc, Dallas, 2018, Hlm 63.

${ }^{3}$ M. Hasan Machfoed et al, Reviewed Article : Does Intra-Arterial Heparin Flushing (IAHF) Can Actually Increase Manual Muscle Test (MMT) Score in Chronic Ischemic Stroke Patients ?, Jurnal Folia Medica Indonesia, Vol 2, No 2, The Center For Medical Science CommunityFaculty of Medicine Universitas Airlangga, Surabaya, 2016, Hlm 150.
} 
motorik di otak. Kedua referensi ini tidak menyebutkan adanya perbaikan stroke dengan pemberian heparin.

Contoh diatas memberikan gambaran bahwa dengan menerapkan hasil temuannya langsung pada pasien, tanpa dilandasi adanya nilai ilmiah yang kuat sebagai dasar penelitian yang dilakukannya, Terawan dapat dikatakan tidak mengikuti perkembangan ilmu kedokteran yang ada, kondisi ini menyalahi aturan yang ditetapkan oleh UUPK baik di penjelasan pasal 2 butir a mengenai nilai ilmiah dan juga pasal 52 bagian e yang menyebutkan bahwa dokter dalam menjalankan praktik kedokterannya mempunyai kewajiban untuk selalu mengikuti perkembangan ilmu kedokteran.

Kasus Terawan juga telah menyalahi aturan standar profesi dalam melakukan pengembangan iptek kedokteran seperti disebutkan oleh Peraturan Pemerintah RI No. 39 Tahun 1995, dengan tidak melanjutkan hasil temuannya ke tahap uji klinis dan mengabaikan nilai ilmiah pembuktian teorinya. Selain itu Terawan juga menyalahi aturan standar profesi yang dikemukakan oleh Leenen, yaitu dia melakukan perbuatan yang tidak teliti dalam hal penelitiannya yang tidak berdasarkan EBM, ceroboh atau lalai dalam penerapan metodenya yang belum teruji pada pasiennya dan tidak melakukan perbandingan manfaat dan kerugian dalam penerapan metodenya sehingga tidak melakukan minimalisasi terhadap resiko yang mungkin akan timbul.

Minimalisasi resiko dan melakukan perbandingan manfaat dan kerugian, harus selalu dilakukan dalam menerapkan temuan bidang teknologi kesehatan, seperti tertera pada penjelasan UUPK pasal 2 butir e dan f yang menyebutkan bahwa dokter harus menjaga keseimbangan dalam praktek, keselarasan antara kepentingan pribadi dalam melakukan kewajiban pengembangan iptek kedokteran dengan kepentingan masyarakat berupa keselamatan pasien. Perlindungan dan keselamatan pasien yang dimaksud adalah, dalam memberikan pelayanan kesehatan dokter harus memperhatikan perlindungan dan keselamatan pasien. Pada kasus terawan hal ini juga tidak diperhatikan, terbukti dengan langsung diterapkannya metode brain wash untuk terapi kasus stroke, tanpa dilakukan dan pengujian kemanfaatan dan kemungkinan resiko 
yang mungkin timbul, padahal tahap ini diperlukan untuk tujuan trial and error yang diujikan pada manusia.

Perlindungan terhadap keamanan dan keselamatan pasien juga tidak hanya dilakukan oleh dokter saja, akan tetapi termasuk dalam lingkungan dimana dia bekerja, misalnya rumah sakit. Rumah sakit mempunyai peran sebagai penyelenggara penelitian, pengembangan dan penapisan teknologi, yang mana proses penapisan teknologi inilah yang akan memberikan perlindungan keamanan dan keselamatan pasien. Hal ini seperti dikemukakan pada Pasal 5 butir d Undang-Undang No. 44 Tahun 2009 Tentang Rumah Sakit. Pada kasus Terawan, institusi tempatnya bernaung seharusnya melakukan fungsi penapisan teknologi ini dengan cermat sehingga penerapan teknologi yang dilakukan memenuhi semua kriteria etika penelitian kesehatan dan sesuai dengan nilai ilmiah yang ada. Pada kenyataannya rumah sakit tempatnya bekerja tidak melakukan fungsi ini, terbukti dengan diterapkannya metode brain wash yang belum memenuhi uji klinis pada pasien-pasien di rumah sakit tersebut. Hal ini bahkan sudah berlangsung selama beberapa tahun.
Pada kasus diatas semestinya Komite HTA melakukan kajian ditahaptahap awal saat inovasi teknologi kesehatan tersebut mulai diterapkan, pada kenyataannya adalah baru setelah kasus ini lama berkembang dan menjadi konsumsi publik dengan menimbulkan berbagai polemik yang menyangkut kredibilitas beberapa pihak, kementrian kesehatan baru memberikan instruksi untuk melakukan kajian terhadap penemuan tersebut.

Badan Penelitian dan Pengembangan Kesehatan (balitbangkes) sebagai bagian dari kementrian kesehatan, yang mempunyai tugas melaksanakan penelitian dan pengembangan di bidang kesehatan, sesuai dengan ketentuan Peraturan Menteri Kesehatan No. 64 Tahun 2015 Tentang Organisasi dan Tata Kerja Kementrian Kesehatan, dapat bekerjasama membantu mengatasi polemik temuan ini dengan merangkul penelitian dan pengembangan teknologi kedokteran yang dilakukan, sehingga sekaligus dapat melakukan pemantauan, evaluasi dan pelaporan dari penelitian yang dilakukan. Bila hal ini dilakukan lebih awal sebelum polemik tersebut berkembang, kemungkinan kasus ini akan terselesaikan dengan baik, dan bila 
seandainya penemuan tersebut dinyatakan efektif dan efisien dapat memberikan manfaat yang besar bagi dunia kesehatan, tentunya hal ini menjadi suatu kebanggaan bagi dunia teknologi kedokteran.

Pasal 28 Undang-Undang praktik kedokteran menyebutkan bahwa setiap dokter yang berpraktek wajib mengikuti pelatihan dan pendidikan berkelanjutan dalam rangka penyerapan perkembangan ilmu pengetahuan dan teknologi kedokteran yang dilaksanakan sesuai dengan standar yang ditetapkan oleh organisasi profesi kedokteran. Organisasi profesi yang dimaksud adalah Ikatan Dokter Indonesia (IDI) yang memelihara dan membina terlaksananya sumpah dokter dan kode etik kedokteran Indonesia (KODEKI).

Dalam hal kasus Terawan dan Gunawan Simon, saat dilakukan pemanggilan oleh MKEK, yang bersangkutan tidak terbuka dalam memberikan informasi dan bahkan mangkir dari panggilan yang seharusnya. Sikap seperti ini melanggar KODEKI Pasal 21, yang menyebutkan bahwa setiap dokter wajib bersifat terbuka, bicara benar, faktual dan sopan santun secara professional pada saat berkomunikasi dengan anggota profesi lainnya.

Suatu penelitian klinis yang belum teruji dengan baik, tetapi sudah diterapkan oleh dokter dalam bidang kesehatan bahkan untuk pengobatan, maka hal ini melanggar KODEKI pasal 6, yang menyebutkan bahwa setiap dokter senantiasa berhati-hati dalam mengumumkan dan menerapkan setiap penemuan teknik atau pengobatan baru yang belum diuji kebenarannya. Pasal ini juga menyebutkan bahwa penelitian baru yang dilakukan, harus telah lolos uji kaji etik dari komite/panitia penilai sesuai dengan ketentuan yang berlaku, dan setiap dokter wajib untuk menerapkan praktik kedokteran berbasis bukti ilmiah yang telah diuji kebenarannya dan diterima dalam standar praktek kedokteran. Prosedur ini telah diabaikan oleh Terawan sehingga menimbulkan polemik saat dia menerapkan metode temuannya pada pasien-pasien yang dia tangani.

Pelanggaran lainnya adalah saat seorang dokter melakukan promosi atau mengiklankan inovasi penemuannya seolah-olah merupakan suatu solusi terbaik yang menyatakan bahwa tindakan tersebut merupakan satu-satunya di 
Indonesia bahkan di dunia, serta menonjolkan hasil kesimpulan yang berlebihan. Hal ini melanggar KODEKI pasal 4 bahwa setiap dokter harus menghindarkan diri dari perbuatan yang bersifat memuji diri.

Seorang dokter yang melakukan penerapan hasil penelitiannya yang belum teruji secara klinis dan memungut sejumlah biaya daripadanya yang tidak sedikit telah melanggar KODEKI pasal 3, Pasal ini menjelaskan bahwa setiap dokter dilarang melakukan perbuatan yang dapat mengakibatkan hilangnya kebebasan dan kemandirian profesi antara lain penerapan ilmu pengetahuan, teknologi, keterampilan kedokteran yang belum berdasarkan bukti ilmiah yang mengakibatkan hilangnya integritas moral dan keilmuannya. Seorang dokter juga dilarang melibatkan dirinya secara langsung atau tidak langsung dalam segala bentuk kegiatan yang bertujuan untuk mempromosikan atau mengiklankan dirinya, Seorang dokter sebaiknya tidak menarik honorarium dalam jumlah yang tidak pantas dan bertentangan dengan rasa perikemanusiaan. Contoh pada kasus Terawan dimana harga yang diterapkan untuk pasien cukup besar dan bervariasi, berkisar antara 23-25 juta, ${ }^{4}$ dan ada juga yang sampai 49 juta. $^{5}$

Kasus diatas juga mengindikasikan adanya pelanggaran dalam etika penelitian kesehatan, yang menyatakan suatu penelitian yang dilakukan harus menganut asas kejujuran (veracity) atau honesty, dimana antara dokter harus bicara jujur mengemukakan hasil pengamatan dan pemeriksaannya kepada pasien apalagi menerapkan suatu metode yang belum teruji secara klinis, selain itu tidak diinformasikan perihal proses, manfaat dan kerugiannya secara benar sehingga pasien tidak memahami sepenuhnya tindakan yang dilakukan pada dirinya. Etik penelitian kesehatan juga mengharuskan bahwa suatu penelitian kesehatan yang akan diterapkan dengan subjek manusia harus melalui serangkaian tahapan uji klinis

\footnotetext{
${ }^{4}$ Haris Prabowo, Biaya Perawatan Cuci Otak Dokter Terawan Rata-Rata 25 Juta, https://tirto.id/biaya-perawatan-cuci-otak-dokterterawan-rata-rata-25-juta-c9SD, diunduh tanggal 8 Mei 2019 pukul 08.36 WIB

5 Widia Wiyanti, Banyak Dipakai Pejabat, Berapa Sih Biaya 'Cuci Otak' dr Terawan, https://health.detik.com/berita-detikhealth/d3957059/banyak-dipakai-pejabat-berapa-sihbiaya-cuci-otak-dr-terawan, diunduh tanggal 8 Mei 2019 pukul 08.11 WIB
} 
yang valid sesuai dengan pernyataan Deklarasi Helsinky.

Kasus diatas akan menimbulkan pelanggaran dalam hal disiplin kedokteran, apabila terbukti menyalahi ranah disiplin kedokteran yang dalam penatalaksanaan tehadap pasien, dokter tersebut melakukan suatu tindakan yang seharusnya tidak dilakukan (commission), atau tidak melakukan tindakan yang seharusnya dilakukan (omission), sesuai dengan tanggung jawab profesionalnya, tanpa alasan pembenar atau pemaaf yang sah, sehingga dapat membahayakan pasien, dalam hal ini dokter menerapkan metode terapi yang belum teruji klinis. Hal ini juga telah menyalahi unsur-unsur standar profesi medis dari Leenen yang mengharuskan seorang dokter bertindak secara teliti, hati-hati, sesuai ukuran medis yang didasarkan pada ilmu medis dan pengalaman dalam bidang medis, dan senantiasa melakukan profesinya menurut ukuran yang tertinggi.

Saat seorang dokter dalam menjalankan praktek kedokterannya telah melakukan tindakan yang tidak teliti, tidak hati-hati dan tidak etis, atau dapat dikatakan dokter tersebut tidak memberikan penjelasan yang jujur, etis dan memadai, hal ini merupakan pelanggaran dari disiplin profesional dokter butir ke-8. Saat dokter yang bersangkutan menjalankan praktik kedokteran dengan menerapkan pengetahuan, keterampilan, atau teknologi yang belum diterima atau diluar tata cara praktik kedokteran yang layak yaitu dengan menggunakan metode brain wash sebagai terapi stroke yang belum diterima sebagai sarana terapi, dan bahkan menerapkan penelitian tersebut tanpa adanya ethical clearance dari lembaga pemerintah, sehingga diragukan mengenai keabsahan penelitian yang dilakukan, maka dokter tersebut dapat dikatakan melakukan pelanggaran disiplin profesional dokter butir ke-13 and butir ke-14. Mengklaim bahwa terapinya sebagai terapi yang terbaik dan bahkan satu-satunya, maka dokter tersebut melakukan pelanggaran disiplin kedokteran butir ke-24 karena mengiklankan kemampuan atau kelebihan baik lisan maupun tulisan yang tidak benar atau menyesatkan.

Pada kasus diatas

Kasus diatas memberikan gambaran bahwa sebetulnya dokter tersebut berusaha menerapkan tanggung jawabnya dalam melakukan 
pengembangan ilmu pengetahuan, penelitian dan pengembangan kesehatan, dimana masing-masing melakukan pengembangan keilmuan dan penelitian sesuai dengan bidangnya, hanya saja ada beberapa yang dirasakan mengganjal dari sisi etika dalam hal implementasi dari hasil penemuan yang dihasilkan. Saat informasi yang diperoleh tidak secara jelas dipaparkan di forum komunikasi antar kolega sendiri, bahkan saat dokter yang bersangkutan dipanggil oleh MKEK untuk mengklarifikasi penemuannya dokter tersebut beberapa kali tidak hadir dalam pertemuan tersebut, hingga akhirnya kasus ini berkembang, dan menimbulkan kericuhan publik pro dan kontra. Pro dari masyarakat yang telah mendapatkan efek positif dari penemuan yang dilakukan dengan mengabaikan proses bagaimana penemuan tersebut dihasilkan, dan kontra dari kalangan peneliti dan profesional medis yang menjunjung tinggi aturanaturan yang ada dalam pengembangan iptek kedokteran. Bila kita telusuri kasus diatas maka beberpa pelanggaran telah dilakukan yaitu pelanggaran, etika penelitian, pelanggaran etika kedokteran, pelanggaran hukum karena berhubungan dengan aturan perundang-undangan yang tidak dilaksanakan dan adanya pelanggaran disiplin profesional dokter yang dilakukan.

Seorang dokter senior yang sudah berpraktik puluhan tahun, rasanya sangat diragukan bila dokter tersebut tidak memahami ranah aturan yang ada disekelilingnya. Dalam menjalankan tanggung jawabnya untuk penerapan pengembangan keilmuan, penelitian dan pengembangan kesehatan sesuai dengan yang diamanatkan oleh peraturan perundang-undangan, dokter tersebut harus selalu mengacu pada aturan-aturan yang mengikatnya sebagai seorang profesional, baik berupa kode etik, standar profesi, SOP, dan aturan lainnya sehubungan dengan aktivitas yang dilakukan.

\section{PENUTUP}

\section{SIMPULAN}

a. Hasil kajian didapatkan bahwa dokter tersebut melakukan penerapan pengembangan ilmu pengetahuan dan penelitian dalam bidang kesehatan/kedokteran yang tidak sesuai dengan peraturan yang ada. Dokter telah menjanjikan suatu hasil (resultaatverbintenis), yang seharusnya hanya menjanjikan upaya 
(inspanningverbintenis), dan telah menerapkan penelitian langsung pada manusia (pasien) tanpa melalui syarat uji klinis dan proses ethical clearance yang berarti dokter tersebut telah mengabaikan prinsip etik umum, dan telah melakukan pelanggaran dari sisi etika penelitian, etika kedokteran, disiplin kedokteran, dan bahkan hukum.

b. Hasil kajian didapatkan penerapan pengembangan ilmu pengetahuan, dan melakukan penelitian yang dilakukan dokter tersebut tidak memenuhi standar penelitian ilmiah yang dipersyaratkan di bidang kesehatan. Penerapan penelitiannya menyalahi aturan Kode Etik Kedokteran Indonesia (KODEKI), dan tidak memenuhi standar ilmu kedokteran berbasis bukti (Evidence Based Medicine. Dokter tersebut juga menyalahi aturan standar profesi medis dalam hal ketidak hati-hatian, kelalaian, tidak memperhatikan keselamatan pasien, dengan cara melakukan penerapan penelitian langsung pada manusia tanpa mempertimbangkan manfaat dan kerugian dalam penerapannya, ditambah dengan lemahnya pengawasan dan pengendalian dari rumah sakit dimana dokter tersebut bekerja, serta terlambatnya proses kajian dari Komite Penilaian Teknologi Kesehatan sehingga kasus ini menjadi polemik. Perilaku yang mengabaikan panggilan MKEK atas dasar dugaan pelanggaran kode etik kedokteran menyebabkan diambilnya keputusan pemberian sanksi secara in absentia.

\section{SARAN}

a. Penerapan pengembangan ilmu pengetahuan dan teknologi serta penelitian kesehatan yang dilakukan oleh dokter harus mengacu kepada peraturan perundang-undangan yang ada, mengkaji ulang penelitiannya dengan melakukan ethical clearance dan uji klinis sesuai pedoman kaidah etika penelitian kesehatan, yaitu dengan cara melakukan uji coba terhadap binatang sebelum diterapkan pada manusia. Pengembangan ilmu dan penelitian yang dilakukan seorang dokter, apalagi yang menyertakan manusia sebagai subjek, harus mengacu pada prinsip etik umum sesuai yang dinyatakan dalam Deklarasi Helsinky. 
b. Ketetapan putusan in absentia untuk dokter berupa pencabutan izin dan pemecatan sementara untuk dokter tersebut, menandakan MKEK dan IDI sangat serius menangani kasus ini. Dokter yang bersangkutan diberikan kesempatan untuk dapat membela dirinya di Muktamar IDI. Untuk keberlangsungan pengembangan penelitiannya, maka dokter tersebut dapat memanfaatkan sarana rumah sakit dimana dokter tersebut bekerja, dibawah pengawasan pemerintah yang melindungi warga negaranya untuk membantu melakukan penapisan teknologi atau melakukan Health Technology Assessment (HTA), agar aspek resiko, manfaat, dan efisiensi dari penelitiannya dapat diketahui dan mampu memberikan dampak positif bagi dunia kesehatan. Pemerintah juga diharapkan dapat membantu memfasilitasi penyelesaian polemik yang terjadi antara pihak peneliti, dan organisasi profesi.

\section{DAFTAR PUSTAKA}

Alauddin, Perlindungan Hukum Kontrak Terapeutik, Genta Publishing, Yogyakarta, 2016.
Bahder Johan Nasution, Hukum Kesehatan Pertanggungjawab Dokter, Rineka Cipta, Jakarta, 2013.

H. M. Ali Firdaus, Dokter Dalam Bayang-Bayang Malpraktik Medik, Widyaparamarta, Bandung, 2017.

Komisi Nasional Etik Penelitian Kesehatan, Buku Ajar Etik Penelitian Kesehatan, Universitas Brawijaya Press, Malang, 2017.

M. Hasan Machfoed et al, Reviewed Article : Does Intra-Arterial Heparin Flushing (IAHF) Can Actually Increase Manual Muscle Test (MMT) Score in Chronic Ischemic Stroke Patients ?, Jurnal Folia Medica Indonesia, vol 2, No 2, The Center For Medical Science Community-Faculty of Medicine Universitas Airlangga, Surabaya, 2016.

M. Jusuf Hanafiah \& Amri Amir, Etika Kedokteran dan Hukum Kesehatan, EGC, Jakarta, 2018.

M. Sajid Darmadipura, Kajian Bioetik, Pusat Penerbitan dan Percetakan Unair (AUP), Surabaya, 2008.

Merdias Almatsier dkk, Himpunan Peraturan Tentang Majelis Kehormatan Disiplin Kedokteran Indonesia, Konsil Kedokteran Indonesia, Jakarta, 2006.

Purwadianto Agus, dkk, Kode Etik Kedokteran Indonesia, Pengurus Besar Ikatan Dokter Indonesia, Jakarta, 2012. 
Evy Silviani Agustina, Tanggung Jawab Dokter Dalam Penerapan Pengembangan Keilmuan, Penelitian Dan...

Soekidjo Notoatmodjo, Etika Dan Hukum Kesehatan, Rineka Cipta, Jakarta, 2010.

Suharyono Putera Taat, Filsafat Ilmu Kedokteran, Airlangga University Press, Surabaya, 2010.

Tim Komisi Nasional Etik Penelitian Kesehatan, Pedoman Nasional Etik Penelitian Kesehatan, Komisi Nasional Etik Penelitian Kesehatan, Jakarta, 2011

William J. Power et al, Guideline For The Early Management of Patients With Acute Ischemic Stroke, American Heart Association, Inc, Dallas, 2018 